\title{
Decline in groundwater levels in Thang Long Industrial Park within the area of Northwest Hanoi, Vietnam
}

\author{
Noboru HIDA*1 and Nguyen Van GIANG*2
}

\begin{abstract}
The purpose of this paper is to urgently report the decline in groundwater levels at Thang Long Industrial Park (TLIP) in the area of Northwest Hanoi, Vietnam. The total pumping capacity in TLIP is $56,970 \mathrm{~m}^{3} /$ day. According to the records of the observation well close to TLIP, groundwater levels have declined since 2008. The amount of decline was approximately $5.67 \mathrm{~m}$ between 2008 and 2011. Lower levels appear in the dry season, particularly in March-April. In order to maintain sustainable use of groundwater in TLIP, one of the issues is to carry out an artificial recharge of groundwater using Kim Hoa Canal, of which water is supplied by the Ca Lo River.
\end{abstract}

Key words: groundwater levels, artificial recharge of groundwater, Thang Long Industrial Park, Hanoi

\section{Introduction}

Hanoi: $21^{\circ} 02^{\prime} 00^{\prime \prime} \mathrm{N} \quad 105^{\circ} 51^{\prime} 00^{\prime \prime} \mathrm{E}$, capital of Vietnam, has an area of 3,344 square kilometers and a population of 6,500,000 in 2010. Downtown of Hanoi is developed on the right bank of the Red River (Song Hong). In and around the downtown area, domestic and industrial water supplies have been relying on groundwater. A public water supply plant using groundwater was constructed first in 1909 with a total pumping capacity of 15,000 $\mathrm{m}^{3} /$ day. At present, the total yield is approximately $700,000 \mathrm{~m}^{3}$ /day, made up as follows: 10 public water supply plants $420,000 \mathrm{~m}^{3} /$ day, relatively big water users such as schools and hospitals $150,000 \mathrm{~m}^{3}$ /day and private household 150,000 $\mathrm{m}^{3}$ /day, respectively (Dan and Dzung, 2002; Khanh et al., 2011, p.5). In the process of the increase, groundwater problems have occurred such as decline of the water table (Fischer et al., 2011), land subsidence (Nguyen and Helm, 1995; Thu and Fredlund, 2000) and groundwater pollution (Berg et al., 2001; Dan and Dzung, 2002).

On the other hand, modern industrial zones have been rapidly established in recent years on the left bank of the Red River, which was once rice paddy fields. In these zones, one of the most significant developments is Thang Long Industrial Park (TLIP), $2.75 \mathrm{~km}^{2}$, located in the northwest of the downtown area. Some factories have been in operation since 2007.

In TLIP, water for industry and drinking is drawn from underground. However, groundwater levels have already declined for the last several years. The purpose of this paper is to urgently report the decline based on observed records. The intention is to explore the way of sustainable use of groundwater in the future, avoiding some similar groundwater problems caused in the right bank area of the Red River. Some results of hydrological and hydrogeological conditions including TLIP have already been published (Giang and Hida 2009

* 1 Akita University, Japan, Professor Emeritus

* 2 Vietnam Academy of Science and Technology (VAST), Hanoi 
and 2010; Hida et al., 2010).

\section{Study area}

\section{II -1 Site}

The site of the study area, within Hanoi City, between downtown and Noi Bai International Airport, is shown in Fig. 1. In this area, the Red River (on the south side) and Ca Lo River (on the north side) flow towards the east.

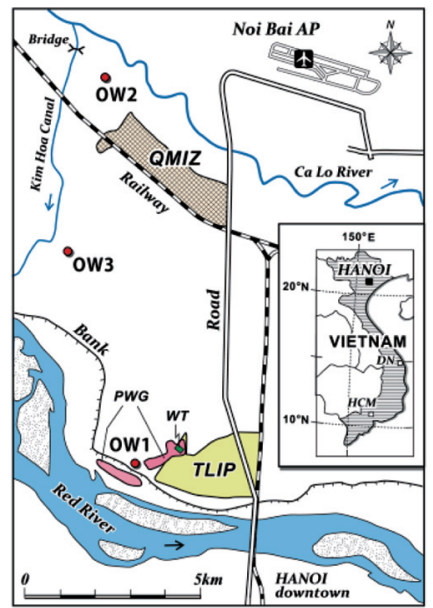

Fig. 1 Study area in Northwest Hanoi. Legend: TLIP: Thang Long Industrial Park, OW: Observation well 1,2,3, PWG: Pumping well gallery (west and east), WT: Water treatment plant, QMIZ: Quang Minh Industry Zone (Base map is by the Topographic Map HANOI and SON TAY (1:50,000), 2001, Hanoi Vietnam.)

\section{II -2 Thang Long Industrial Park (TLIP)}

TLIP bordering on the Red River is an important industrial zone in Hanoi, which was completely reclaimed in 2007. Industrial water sources are limited to groundwater. In addition, Quang Minh Industrial Zone (QMIZ) exists in the north, where groundwater yield is small.

\section{II -3 Groundwater yield in TLIP}

Pumping well gallery (PWG)-west and PWGeast are located on the west side of TLIP (Fig. 1). Eight pumping wells each have been constructed in the PWG-west (inside the river bank) and in the
PWG-east (outside the river bank). Wells in the PWG-west are 57 - 66m deep, each with pumping capacity of 4,320 $\mathrm{m}^{3} /$ day. Total pumping capacity of the eight wells is $34,560 \mathrm{~m}^{3} /$ day. Wells in PWG-east are $62-67 \mathrm{~m}$ deep. The pumping capacity of each is $2,800 \mathrm{~m}^{3} /$ day, and the total for the eight wells is $22,400 \mathrm{~m}^{3} /$ day. The total pumping capacity of all 16 wells is $56,970 \mathrm{~m}^{3} /$ day. All of the groundwater is withdrawn from the Pleistocene aquifer mentioned later.

\section{II -4 Physical environment}

Climate: Hanoi belongs to the monsoon region. A hydrological year consists of a rainy season from May to October, and a dry season from November to April.

Topography: The study area is a floodplain formed by the Red River and Ca Lo River (DGMV, 2005). The ground surface is almost $10 \mathrm{~m}$ above sea level and inclined from the side of the Ca Lo River towards the side of the Red River approximately in $1.0 \times 10^{-2}(\mathrm{HXBBD}, 2001)$.

Hydrogeology: Most of the groundwater in the Red River Delta including the study area is contained in Quaternary sediments (Lan et al., 2007). The aquifer is composed of two layers, the upper Holocene aquifer (Qh) and the lower Pleistocene aquifer (Qp). The thickness of $\mathrm{Qh}$ is estimated to be $10-15 \mathrm{~m}$ and that of Qp is about 20-40m (Dan and Dzung, 2002; DGMV, 2005). Characteristic properties of these two in the Red River Delta have been discussed in detail (Bui et al., 2012; Giang et al., 2012; Jusseret et al., 2010; Hori et al., 2004).

\section{Observation wells}

Three observation wells: OW1, OW2 and OW3 were established in the study area. OW1 is substantially situated in the middle of PWG-west and PWGeast of TLIP (Fig. 1). OW2 and OW3 were placed to the north of OW1. Specifications and geologic 
Table 1 Specifications of the OW1, OW2 and OW3.

\begin{tabular}{|c|c|c|c|}
\hline Items & OW1 & OW2 & OW3 \\
\hline \multirow[t]{2}{*}{ Site (See Fig. 1) } & $105^{\circ} 54^{\prime} 20^{\prime \prime} \mathrm{E}$ & $105^{\circ} 45^{\prime} 00^{\prime \prime} \mathrm{E}$ & $105^{\circ} 44^{\prime} 05^{\prime \prime} \mathrm{E}$ \\
\hline & $21^{\circ} 06^{\prime} 57^{\prime \prime} \mathrm{N}$ & $21^{\circ} 12^{\prime} 20^{\prime \prime} \mathrm{N}$ & $21^{\circ} 10^{\prime} 24^{\prime \prime} \mathrm{N}$ \\
\hline Ground level (Elv. m) & 10.0 & 10.0 & 8.0 \\
\hline Well head (Elv. m) & 10.0 & 11.2 & 8.0 \\
\hline Depth $(\mathrm{m})^{(1)}$ & 60.0 & 48.0 & 40.0 \\
\hline Screen length $(\mathrm{m})^{(2)}$ & 8.0 & 4.0 & 4.0 \\
\hline Diameter, (mm) & 90 & 90 & 90 \\
\hline Logger & \multicolumn{3}{|c|}{ Water level and Water temperature } \\
\hline Recorded by logger & & from July 2008 & \\
\hline Construction & March 2008 & June2008 & July 2008 \\
\hline $\mathrm{GCS}^{(3)}$ & & See Fig. 2 & \\
\hline
\end{tabular}

Notes : (1) Drilling depth from ground level (m)

(2) Installed at the bottom of the well, See Fig. 2

(3) Geologic columnar section

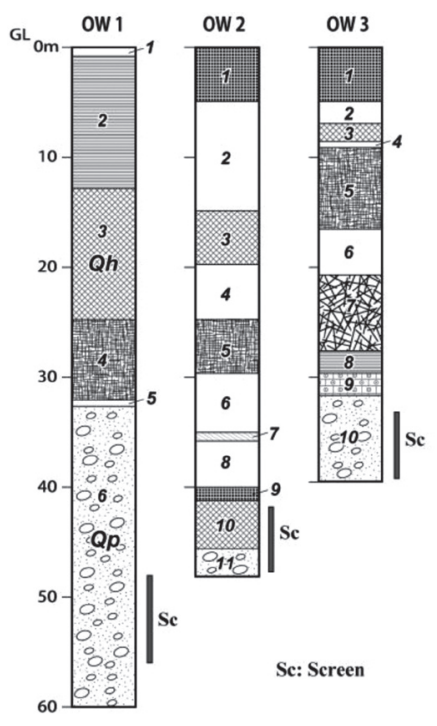

Fig. 2 Geologic columnar section of the OW1, OW2 and OW3, delineated by boring cores. Legend: Petrography OW1: 1 Soil, 2 Mixed clay, 3 Mixed sand, 4 Silt clay, 5 Grit stone, 6 Block pebbles and coarse gravel OW2: 1 Soil and softred clay, 2 Medium separate-yellow sand, $3 \mathrm{Me}-$ dium separate-grey sand, 4 Pebbles $(4 \mathrm{~cm})$ and coarse-grey sand, 5 Medium light-yellow sand, 6 Medium yellow sand, 7 Soft clay, 8 Medium yellow sand, 9 Soft-black clay, 10 Medium grey sand, 11 Gritstone OW3: 1 Soft red clay, 2 Soft yellow clay, 3 Black clay, 4 Yellow separate sandclay, 5 Medium yellow sand, 6 Yellow-soft clay, 7 Coarse gravel and yellow sand, 8 Medium black sand, 9 Medium yellow sand, 10 Pebble $60 \mathrm{~mm}$ and coarse yellow sand

(OW1: layer 3 corresponds to $\mathbf{Q h}$ aquifer and layer 6 corresponds to $\mathbf{Q p}$ aquifer) columnar section of the three wells are shown in Table 1 and Fig. 2. A screen installed in OW1 is in the layer of the lower Pleistocene aquifer (Qp).

A logger to record groundwater level and temperature was inserted to the depth of $15 \mathrm{~m}$ from the surface in each well. The recording interval of each was one hour.

\section{Results: decline in groundwater levels at OW1}

Annual change in groundwater levels (Elevation $\mathrm{m}$ : Elv. $\mathrm{m}$ ) at OW1 in Thang Long Industrial Park is shown in Fig. 3 which is based on the observation records of daily mean from 2008 to 2011 hydrological year (hy). Table 2 shows average groundwater levels (Elv. m) at OW1 by hydrological year, by rainy and dry seasons, and by month in the dry season. Fig. 3 and Table 2 do not include the records for April 2011hy due to the lack of records. The findings based on Fig. 3 and Table 2 are as follows.

Firstly, groundwater level has been declining every year since 2008 hy. In the four years from 2008hy to 2011hy the highest level was $4.87 \mathrm{~m}$ on August 15, 2008 and the lowest one was $-6.9 \mathrm{~m}$ on March 02, 2012. The difference between the two reached $11.85 \mathrm{~m}$, which is the maximum fluctuation during this period (Fig. 3).

Secondly, annual average groundwater level 


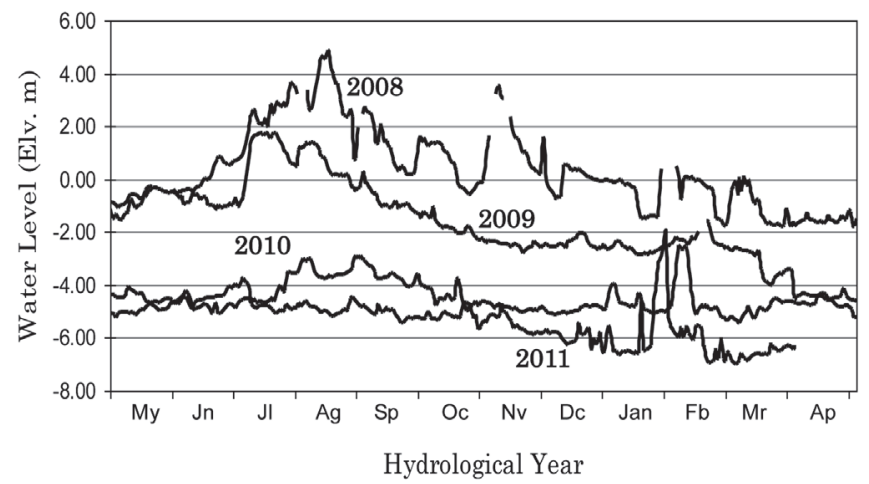

Fig. 3 Annual changes in groundwater levels at OW1 in Thang Long Industrial Park, 2008 - 2011 hydrological year.

Table 2 Average groundwater levels (Elv. $\mathrm{m}$ ) by hydrological year, by rainy and dry seasons and by month in the dry season.

\begin{tabular}{lrrrc}
\hline & 2008 & 2009 & 2010 & 2011 \\
\hline Hydr Year & 0.30 & -1.72 & -4.47 & -5.37 \\
Rainy Season & 1.05 & -0.48 & -4.19 & -4.85 \\
Dry Season & -0.50 & -2.94 & -4.75 & -5.84 \\
$\mathrm{Nv}$ & 1.23 & -2.48 & -4.87 & -4.87 \\
$\mathrm{Dc}$ & 0.02 & -2.42 & -4.90 & -5.91 \\
$\mathrm{Jan}$ & -0.68 & -2.62 & -4.73 & -5.65 \\
$\mathrm{Fb}$ & -0.55 & -2.30 & -4.40 & -6.26 \\
$\mathrm{Mr}$ & -1.09 & -3.30 & -4.88 & $\mathbf{- 6 . 5 6}$ \\
$\mathrm{Ap}$ & $\mathbf{- 1 . 5 3}$ & $\mathbf{- 4 . 4 4}$ & -4.70 & * \\
\hline
\end{tabular}

*The data of April in 2011hy is unorganized.

was $0.30 \mathrm{~m}$ in $2008 \mathrm{hy},-1.72 \mathrm{~m}$ in $2009 \mathrm{hy},-4.47 \mathrm{~m}$ in 2010hy and $-5.37 \mathrm{~m}$ in 2011hy (Table 2). Based on these numbers, the amount of decline in groundwater level was $2.02 \mathrm{~m}$ between $2008 \mathrm{hy}$ and $2009 \mathrm{hy}$, $2.75 \mathrm{~m}$ between $2009 \mathrm{hy}$ and $2010 \mathrm{hy}$ and $0.96 \mathrm{~m}$ between 2010hy and 2011hy, and the amount of decline has reached approximately $5.67 \mathrm{~m}$ in the four years from 2008hy to 2011hy. This decline appears to be due to an increase in the amount of pumping. For instance, a pumping well G17, located 200 m north of OW1, was installed in 2008 and began pumping in 2009. Wells in the PWG-west have been running since the second half of 2009 .

Thirdly, the average value of the groundwater levels in the dry season of each hydrological year is lower than the value in the rainy season (Table 2).
The groundwater level in the dry season is $1.55 \mathrm{~m}$ lower than that in the rainy season in 2008hy, $2.46 \mathrm{~m}$ in $2009 \mathrm{hy}, 0.56 \mathrm{~m}$ in $2010 \mathrm{hy}$ and $0.99 \mathrm{~m}$ in $2011 \mathrm{hy}$. From these, it is evident that the lower groundwater level appears in the dry season of each year.

Fourthly, only in the dry season, the average value of the groundwater levels of each month is shown in Table 2. As shown in the table, the lowest groundwater levels appeared in April in 2008hy and 2009hy, in December in 2010hy and in March in 2011hy. As a trend, the critical decline of groundwater levels appears in the second half of the dry season, around March and April in particular.

In contrast, the groundwater levels at OW2 and OW3 have not changed as the level at OW1. In the time from 2008hy to 2011hy, OW2 records were in a range of approximately 2.5-3.0 Elv. $\mathrm{m}$ and OW3 showed a nearly stable level of $-1.2 \mathrm{Elv}$. $\mathrm{m}$. The reasons of these small fluctuations seem to be due to the distance from TLIP, the depth of screens and the hydraulic gradient towards the south. In this paper, these details are not considered.

\section{Concluding remarks}

Firstly, the following points are noted regarding the groundwater level at OW1. (1) The groundwater level has declined since 2008. The amount of decline 
reached approximately $5.67 \mathrm{~m}$ in between 2008 hy and 2011hy. (2) The groundwater level appears lower in the dry season of each hydrological year, especially in March and April, and higher in the rainy season. (3) Why does the groundwater level rise during the rainy season? The reason seems to be that the water level of the Red River is rising in the rainy season and the infiltration and recharge from ground surfaces is increasing as well. Details will be analyzed in the future.

Secondly, the decline of groundwater level at OW1 is considered to be due to the large amount of pumping within TLIP. If this condition continues, the depletion of groundwater will eventuate in the near future. Companies that have expanded into TLIP should watch this situation carefully.

Thirdly, one of the urgent issues is to find methods to use the groundwater sustainably (Fischer et al., 2011; Hida, 2009; United Nations, 2012). An effective tool is to apply an artificial recharge of groundwater to the area of TLIP. In terms of quantity and quality, the water of the Ca Lo river is suitable as a source for the artificial recharge (Hida $e t$ al., 2010), and Kim Hoa Canal (Fig. 1) can be used as a recharge ditch.

\section{Acknowledgement}

This study was supported by JSPS KAKENHI: Grant-in-Aid for Scientific Research (B), No.19401002 in 2007-2010 and Grant-in-Aid for Challenging Exploratory Research, No.23650578 in 2011-2013. Thanks are also for useful suggestions by the referees.

\section{References}

Berg, M., Tran, H. C., Nguyen, T. C., Pham, H. V., Schertenleib, R. and Giger, W. (2001): Arsenic contamination of groundwater and drinking water in Vietnam: A human health threat. Environmental Science and Technology, 35, 2621-2626.

Bui, D. D., Kawamura, A., Tong, T. N., Amaguchi, H. and Trinh,T. M. (2012): Aquifer system for potential groundwater resources in Hanoi, Vietnam. Hydrological Processes, 26, 932-946.

Dan, N. V. and Dzung, N. T. (2002): Groundwater pollution in the Hanoi area, Vietnam. http:// publications.iwmi.org/pdf/H033493.pdf A4, 7p.

DGMV: Department of Geology and Minerals of Vietnam (2005): Geological and mineral resources map of Vietnam HA NOI (F-48-XXVIII) 1:200,000. Hanoi. (in Vietnamese with English notes)

Fischer, A. R, Stefan, C., Silabetzschky, K., Werner, P. and Bui Hoc, B. (2011): Soil aquifer treatment as a tool for sustainable groundwater use in Hanoi/Vietnam. Jnl. of Environmental Protection, 2, 882-887.

Giang, N. V. and Hida, N. (2009): Study of hydrological characteristics and hydrogeological conditions for management of aquifer recharge in NW Hanoi area. Jnl. of Geologia, ISSN 01380974; Uczelniane wyd. Naukowo-dydaktyczne AGH, Krakow; Tom 35(2/1), 463-472.

Giang, N. V. and Hida, N. (2010): Efficient groundwater management approach for North Thang Long and Quany Minh industrial zones - Hanoi, Vietnam. XXXVIII IAH Congress, Krakow, 12-17 Sept 2010, Poster No. 323.

Giang, N. V., Hida, N. and Bano, M. (2012): The characteristics of shallow geological sturucture for Red River side - Tayho - Hanoi area by geophysical data. Jnl. of Scienses of the Earth, VAST, 34, 97-106. (in Vietnamese with English summary)

Hida, N. (2009): Managed aquifer recharge by using spreading basin methods on alluvial fans: a general overview of the situation in Japan. BOLETÍN GEOLÓGICO Y MINERO (special issue devoted to artificial recharge of groundwater), Institudo 
Giologico y Minero de Espana, Spanish Geological Survey (IGME), 120, 311-320.

Hida, N., Giang, N. V. and Kagabu, M. (2010): Groundwater level, groundwater temperature and water quality of the Hanoi northwest Thang Long industrial zone: A project aimed at artificial recharge of groundwater. Proc. of JAGH Japn. Association of Groundwater Hydrology, Wakayama, 11-13 Nov. 2010, 280-281. (in Jpanese)

Hori, K., Tanabe, S., Saito, Y., Haruyama, S., Nguyen, V. and Kitamura, A. (2004): Delta initiation and Holocene sea-level change: example from the Song Hong (Red River) delta, Vietnam. Sedimentary Geology, 164, 237-249.

HXBBD (2001): Topographic Map HA NOI and SON TAY (1:50,000), Hanoi Vietnam. (in Vietnamese)

Jusseret, S., Baeteman, C. and Dassargues, A. (2010): The stratigraphical architecture of the quaternary deposits as support for hydrogeological modelling of the central zone of Hanoi (Vietnam). Geologica Bergia, 13, 77-90.

Khanh, N. V., Son, N. M. and Hien, H. N. (pdf in 2011): Main pollution issues of groundwater in
Hanoi, Vietnam. http://asemwaternet.org/fileserver/ forum/WPPOLLUT_02.pdf

Lan, N. T., Nghi, T., Mai, D. and Thanh, D. X. (2007): Characteristics of Quaternary sedimentary facies in relation to water bearing capacity of aquifers and aquicludes in the Red River Delta, Vietnam. VNU Jnl. of Science, Earth Sciences, 23, 170-176.

Nguyen,T.Q. and Helm,D.C. (1995): Land subsidence due to groundwater withdrawal in Hanoi, Vietnam. IAHS Publ, no 234, 55-60.

Thu, T. M. and Fredlund, D. G. (2000): Modelling subsidence in the Hanoi City area, Vietnam. Canadian Geotechnical Journal, 37, 621-637.

United Nations (2012): Resilient People, Resilient Planet: A future worth choosing, The report of the United Nations Secretary-General's High-level Panel on Global Sustainability. United Nations Sales No. E. 12. I. 2, New York, N Y., UN, 94p.

(Received July 21, 2012)

(Accepted Oct. 03, 2012)

この論文に対する「討論」を2013年 5 月31日ま で受け付けます。

\section{ハノイ北西部のタンロン工業団地における地下水位の低下}

\section{肥田 登・ Nguyen Van GIANG}

\section{要 旨}

小論は，ベトナム，八ノイ北西部，タンロン工業団地における地下水位の低 下について報告する。団地の日可能総揚水量は $56,970 \mathrm{~m}^{3}$ である。工業団地に隣 接する観測井の記録によると，地下水位は 2008 年から低下し，2008 年から 2011 年までの間に低下量はお扎よそ $5.67 \mathrm{~m}$ に達した。低下は年間を通してみると乾 季，特に $3-4$ 月に現れる。この団地の地下水利用を持続させるためには， $\mathrm{Ca}$ Lo 川の水を引いている Kim Hoa 水路を用いて地下水人工涵養を実施することが 考えられる。

キーワード : 地下水位，地下水人工涵養，タンロン工業団地，八ノイ 